\title{
Ruined time and post-revolutionary allegory in Nthikeng Mohlele's Small Things
}

\author{
Timothy Wright \\ Department of English, Bilkent University, Ankara, Turkey
}

\begin{abstract}
This paper reads Nthikeng Mohlele's 2013 novel Small Things with a view to understanding a qualitative shift in South Africa's postapartheid historical consciousness: an emergent sense of being in "exile from history." This is not simply a relationship to history of being "post," but rather a melancholic attachment that cannot be fully relinquished. I use this lens to understand the dark satire of Mohlele's novel of Johannesburg flânerie and unrequited yearning, a narrative which seems to foreclose the forms of generative encounter so central to urban aesthetics in post-apartheid South Africa. My aim in this article is to distinguish the political desires in this novel both from the revolutionary energies and imaginaries of the liberation struggle, as well as from more recent and optimistic work on urbanism or the energies of the various fallist movements. By contrast to these, Mohlele's novel suggests that liberation might take traumatic and melancholic forms. I argue that this is not post- or anti-political literature, nor a literature of disillusionment, but rather the negotiation of a new relationship with political time that allows the post-apartheid subject to maintain an increasingly tenuous relationship with what David Scott calls the "allegory of emancipationist redemption."
\end{abstract}

\section{KEYWORDS}

Post-apartheid literature; temporality; Johannesburg

There is a striking moment of uncanny political recognition in the 2015 art film Necktie Youth. The camera, which has tracked the lives of a group of wealthy "born frees" as they aimlessly navigate the northern suburbs of Johannesburg in a narcotic haze, partying, idling, musing on existential questions, alights for a brief moment on a portrait of Nelson Mandela adorning the plush walls of one of the suburban Johannesburg mansions that serve as their playground. This is not Mandela the fiery young political freedom fighter, but Mandela the old, triumphal sage, burnished into an icon. There is something unsettling about this portrait: it does not represent struggle but rather the end of struggle. One could go further: in the context of this film, whose margins are haunted by a stark and impoverished urban underclass, this Mandela signals a utopian promise betrayed.

In Conscripts of Modernity, his magisterial study of The Black Jacobins, David Scott argues that C.L.R. James's study gave to the events of the Haitian revolution "the shape of an allegory of emancipationist redemption that embodies in a compelling way the 
great longing for black and anticolonial revolution" (2004, 57). But now, Scott claims, "the critical purchase of this allegory is less than what it formerly was. Much less ... this story is an exhausted one" (57). What is so striking about the image of Mandela above is that it marks the passage of South Africa's "allegory of emancipationist redemption" from the status of living narrative structure into that of historical sign. Hlonipha Mokoena, in her meditations on the black hero in post-apartheid South Africa, has suggested that the loss of this allegory might be liberating, allowing for new black identities to be built around the task of "interpretation" rather than merely on the "affirmation of political ideologies" (2015, 177). Without disputing Mokoena's claim, I want to explore the possibility that this "liberation" from the allegory of emancipatory redemption might not be in any way straightforward, and might rather take traumatic and melancholic forms.

Take for instance the raft of putatively existentialist fictions by black writers that have appeared since 2012. To name a few: Sibs Shongwe-La Mer's Necktie Youth (2015), Masande Ntshanga's The Reactive (2014), and - the subject matter of this essay Nthikeng Mohlele's Small Things (2013). These works are set in vibrant post-apartheid cities redolent of possibility. Their protagonists, both black and white, are not restricted by their racial identities, and the political afterlives of the anti-apartheid struggle are peripheral to the protagonists' concerns. Yet they are marked by a sense of anomie and ennui. These are texts filled with loss and disappointment.

The relationship to history I am diagnosing, then, is not simply one of being "post." These are all texts that explore the condition of what Michele Magwood has called "exile from history" (quoted in Malec 2015). They explore the pathologies of lives that are absent the historical narrative of struggle that would, in an earlier time, have imparted meaning to them. What has happened here is not so much liberation in the loss of the allegory, but rather the emergence of various eccentric, ironic, or melancholic forms of relation to it.

Exile from history: a pregnant concept. Exile is usually a spatial category. What does it mean when one is exiled from a sense of belonging in time? To answer this, let me turn to another study by David Scott. In Omens of Adversity, his analysis of the aftermath of the failed Grenadan revolution of 1978, Scott writes of a changing sense of time in the aftermath of a revolutionary event. Time now becomes discernible as something that stands apart from history. In Scott's evocative phrasing, this is a "ruined" time, "betrayed by history" $(2014,6)$. This time is marked by a sense of afterness: "the trace of futures past" hangs over an "endlessly extending present" (6). Ruined time is not the same as Benjamin's homogenous empty time. Rather, it is a time that bears the imprints of a future that did not come to pass. ${ }^{1}$ Scott's analysis applies to the collapse of any structure of historical expectation. Of course, South Africa is not Grenada. As Njabulo Ndebele has noted, the anti-apartheid struggle was neither quite failed not quite fulfilled (see Wenzel $2009,161)$. That is, it was ambiguous: successful enough to dampen the sense of revolutionary time that structured the anti-apartheid struggle, but not quite successful enough to extinguish it. The allegory of emancipationist redemption thus continues to exert force on the South African imagination. It is an allegory that, to use Jennifer Wenzel's term, is "unfailed" (2009). South Africa's post-revolutionary time therefore possesses a dynamic turbulence in which the hegemony of neo-liberal time is always under threat from the return of a reborn revolutionary time. ${ }^{2}$ The works I mention above thus mark a paradigm 
shift in South Africa's "post-revolutionary" time. If the South Africa of 1994 to 2012 was haunted by the spectre of apartheid, most visibly in its obsession with the Truth and Reconciliation Commission (TRC), South Africa post-2012 can broadly be said to be haunted by a new ghost: the ghost of 1994 itself. ${ }^{3}$ And while the ghosts of apartheid appear as revenants to be exorcised, the ghost of 1994 by contrast offers glimpses of a still breathing utopian desire that was missed, or at any rate not fully achieved. To banish them would be to excise a part of the post-apartheid nation's self. In this sense, 1994 has become an object of melancholia, an object of desire that cannot quite be relinquished. ${ }^{4}$ This paper could proceed in two directions. One of these would be to examine the experience of "born frees" like those of Necktie Youth, exiled from history in the sense of having been excluded by virtue of youth from the grand narrative of anti-apartheid struggle. I leave this avenue aside for now. In this paper, I will take up instead another exilic condition: that of those who participated in anti-apartheid history, yet found themselves after 1994 without its ennobling framework. To this end, I examine a little commented on novel by Nthikeng Mohlele, Small Things (2013). I choose Mohlele as my subject because his protagonists have fraught relationships with the allegory of emancipationist redemption, and this particular novel, because it focuses on a space in the postapartheid imaginary so often charged with carrying the impetus of transformation: the city of Johannesburg. It is a novel that not only explores exile in multiple registers - the temporal, the spatial, the allegorical, the historical - but internalises it into its narrative and plot structure.

\section{Post-revolutionary anomie}

A sardonic wariness of historical time pervades Mohlele's novels. Set in locales rich with the ghosts of anti-colonial romance (his first novel, The Scent of Bliss [2008], is set in a fictional "Lumumbaville"), they follow aesthetes concerned with desire and beauty who somehow find themselves caught up in the mainstream of history. There is something of Nabokov in their sophisticated tastes, something of Coetzee in their wilfully obscure protagonists, and something of García Marquez in the voluptuous way these protagonists resign themselves to the vicissitudes of political and personal disappointment. The wry, stylised narratives of aesthetes hurt by disappointment, they display none of the grittiness or hustle that generally characterises the post-apartheid black urban voice. His protagonists - refined aesthetes all - have lived through both struggle and its aftermath, and in so doing have developed fraught, melancholic relationships with the allegory of emancipationist redemption. A stylistic tic marks all his work: the recurrent syntactical separation of the narrating "I" by an intervening clause from its verb. (The first line of Small Things: "I, in my own determined and peculiar ways, to certain approximate and exact degrees, don't think much of life" $[2013,3])$. His protagonists are detached, via a layer of aesthetic refinement, from the fallen worlds they invariably inhabit. ${ }^{5}$ Small Things is no exception. An impressionistic, compact first-person novella, it is narrated by a nameless protagonist whom we know only by his ironic nickname, "Che." Che comes of age in the ferment of Johannesburg's Sophiatown - the "locus of a dazzling new cosmopolitan world" (Nuttall 2004, 740) - where he falls for the haughty and unattainable Desirée. When the district is bulldozed under the Group Areas Act, Che is relocated to Meadowlands, Desirée to Alexandra. In the furious throes of mourning, Che throws himself into political journalism. Jailed for 18 years for an incendiary piece attacking 
the apartheid regime, he is ejected into a newly democratic and crime-ridden Johannesburg through which he drifts restlessly, taking odd jobs, entering into hopeless romances, engaging in philosophical musing and wandering the city "[l]ike a stray dog...[i]n search not of food, but of meaning" (Mohlele 2013, 9).

There are thus two temporal trajectories in the novel: a diachronic one recalled by Che, in which he enters into and is ejected from revolutionary time, and a synchronic one of a present evacuated of historical movement. The novel thus brings into focus the problem of historical meaning. One symptom of this is Che's refusal to divulge any details of his political activity or "to say for which belief, which idea, he endured such suffering" (Mohlele 2013, 84). Belief in a greater cause is of course what makes suffering bearable, subsuming it within a collective project that will yield a future benefit. The loss of this future creates an affective knot in which Che cannot let go of the historical cause while at the same time he cannot bring himself to enunciate it.

In an insightful review, Joshua Maserow (2014) writes of the book that it is "an extended thought experiment" asking the question "how does one attain freedom after emancipation, if the withdrawal of overt oppression is the first step on the journey to freedom?" I am sceptical of the implicit teleology of Maserow's claim, but his splitting of the question of freedom from the official narrative of historical emancipation is a valuable key to the novel's concerns. The novel presents a world in which the revolutionary impulses, desires, and projections of the struggle era have been, as I suggested, turned into a sign. Che's own life bears evidence of this: prior to imprisonment, he participates in the struggle, in his own minor way, through his journalism. After his release, he procures a job as, among other things, a struggle history guide: a position that tellingly confines struggle to the past.

In short, this is a novel depicting the exit from revolutionary time - a time of expectation and overcoming - into a world of temporal stasis which, as Scott puts it, it is hard to imagine "as though it were merely writing for its own dialectical overcoming" $(2014,6)$. Despite a surface restlessness, the novel's plot, such as it is, contains little in the way of progressive momentum: Che finds love, he loses love; he finds a job, he loses a job; he adopts a dog, he loses the dog. Yet at the same time the narrative is propelled by a recurrent desire for something more - the somewhat ham-fisted "quest for meaning" - perturbing the present. The incessant movement that characterises this text stems from a desire to forge some relationship to historical meaning, as the traversal of space substitutes for the calcification of time. It is a city novel driven not by the kineticism of encounter, but rather by an affective kernel of profound disappointment: a disappointment in the arrival of what seems to be the wrong future.

\section{The disappointed city}

There is a tradition of reading the post-apartheid city as a space that breaks from the telos of national time and enacts localised forms of becoming and remaking. A spate of film, fiction, and criticism over the past two decades has latched on to an image of Johannesburg in particular as a space of transformation, of improvised forms of being and sociality, of becomings: of the city as a catalyst for change. In short, post-apartheid Johannesburg has been granted, in the national imaginary, the symbolic capacity to re-enchant the stalled temporality of the nation. 
The most powerful articulation of this view is Sarah Nuttall's proposal, in her seminal essay "City Forms and Writing the 'Now' in South Africa" (2004), that post-apartheid city writing is effectively charged with an insurgent nowness able to remake the past. ${ }^{6}$ At the heart of Nuttall's essay is a reading of a cluster of Johannesburg texts in which acts of walking and naming grant the subject power over the lingering apartheid-era meanings attached to concrete structures. Phaswane Mpe's Welcome to our Hillbrow (2001), for example, "offers a revised itinerary of the city, both tracking and breaching historical constructions of city space" (Nuttall 2004, 743). Street names, which "mark the trace of colonial and apartheid epistemologies and practices" now "detach themselves from the places they were supposed to define and serve as imaginary meeting points on divergent itineraries" (743). Behind Nuttall's readings of a text like Welcome is an implicit sense of the potency of the "now" in the post-apartheid urban landscape. In invoking the power of the "now" - with its echoes of Benjamin's now-time - the essay gestures to a present that has an agential power over the past. I contend, however, that the intervening 13 years since Nuttall wrote this essay have seen a qualitative degradation in the status of the "now" and in the possibilities it offers. The now, considered as a pure present, no longer appears as a space of emancipation and remaking. Rather, the now post-2012 locks the subject into a no-man's land cut off from past and future, without whose horizons the present cannot be evaluated or transformed. This is, if not an outright revulsion against the now, at the very least a disenchantment with it.

I want to submit that we have, post 2012, entered into yet a new temporal moment, in which, what Andrea Spain identifies as the fissure between "promise" and "encounter" (2016), is in the process of being replaced by a thematics of disappointment and ruin. This is true even in Johannesburg: as Loren Kruger notes, 2012 sees the beginning of a "necessarily critical disenchantment of the 'wonder city' in the face of discontent about inequity and broken promises" $(2013,198)$. The kind of temporality yielded in this novel's movement is that of Scott's "ruined time": a time not merely empty and homogenous, but bearing the imprints of futures past.

If the writings on which Nuttall based her argument were haunted by an apartheid past, Small Things is haunted by the ideals and expectations attached to the anticipated postapartheid future. Although on the surface it seems a familiar kind of Johannesburg narrative, with its fragmented cityscape and seedy, crime, ridden, dog-eat-dog atmosphere, Small Things presents a Johannesburg itinerary that is in key ways different from that described by Nuttall. This is a city in which perambulation and border crossing is eminently possible. Yet, despite the ease of urban traversal, Che's movement lacks the agential charge ascribed to it by Nuttall. The novella presents a city that is geographically unified yet temporally out of joint. In Che's strolls through the city, we experience the homogeneous empty time of post-history. This time is made visible in the novel through Che's endless walking through neighbourhoods that merely impress upon him the contours of a present in which he has no say. Far from offering the opportunity to make or remake the city, they offer this:

Corlett Drive takes me past unremarkable sights, the occasional belch of diesel smoke from construction trucks and metro buses..Blue lights flash in the distance. I see police frisking people, lining them up against walls. An impromptu detour, an early right turn, lands me at Melrose Arch, passing beautiful women throwing their heads back in staged laughter. (Mohlele 2013, 92) 
These walks serve less to create a sense of urban modernity à la Baudelaire than to create a sense of a history-less present. Despite the fact that this suburban wasteland we are here in the formless, unlovely suburbs of Johannesburg - is marked by a sense of "wrongness" (police frisking, staged laughter), it is stripped of any deeper significations and movements that might alter it.

Is this to say the novella is merely a retreat from the political, uninterested in the transgressive and utopian energies that flow through the city? Not at all: it is a fiction about the failure of promise and expectation. This is a hauntology of the city, to use Derrida's evocative phrase, interested not in its fluid and vital present, but in its ghosts, its silences, its futures past. It is foremost a city haunted by the utopian.

This is emblematised by the structure that anchors Che's flânerie, a monumental urban symbol of linkage both physical and symbolic: Nelson Mandela Bridge. ${ }^{7}$ Conceived in 1993 and completed a decade later, the bridge straddles two worlds of Johannesburg: the impoverished inner city, home primarily to black migrants, and the wealthy, predominantly white northern suburbs. In 2010, rainbow-coloured lighting (to echo the "rainbow nation") was installed. One of the few post-1994 additions to the city skyline, Mandela Bridge is one of the most visible and symbolically pregnant of postapartheid urban interventions: a concrete expression the uniting of South African society and of the so-called "rainbow nation" that its namesake inaugurated. ${ }^{8}$ Mandela Bridge functions foremost to show up the fallen present. Witness the scene in which it serves as the stage for the most dramatic scene of the novel: a violent assault on the narrator by an anonymous flâneur referred to as the "Dark Figure." A flamboyant loner exuding a crass Americanness, the Dark Figure fashions himself as an American gangster, his speech littered with slang to the point that the comically refined Che barely understands him. An interaction that begins with the Dark Figure asking Che for a cigarette escalates until it becomes a referendum on Che's right to exist. At its culmination, the Dark Figure draws a gun and shoots Che three times - to which Che responds as follows:

Something about the gunshots is marvellous: the deafening explosions, the flash of angry blue flame, the intoxicating smell of gunpowder. Those seconds, time between the shots, the tense moments of unpredictable consequences, are the closest one gets to a God experience - that complete tranquillity of a brutalised body numbed of all feeling, as The Dark Figure aims his gun with random abandon. My fading mind feeds me enchanting views of the Nelson Mandela Bridge, of the city, unlike any other spot in the temptress flirt that is Johannesburg. (Mohlele 2013, 23)

This scene rewrites the famous arbitrary killing that concludes Albert Camus's The Stranger (1942), and in so doing signals again its affinity for a quasi-existentialist world view. We inhabit a world of contingency unstructured by any overarching historical narrative. In the absence of this, "meaning" has no easy structure on which to latch itself and emerges as simply the expression of a force of will, as the potency of a discrete localised act.

Striking about this passage is the way its stylistic sheen effectively blocks out the possibility that this moment of intense physical violence might hold a disruptive possibility. Rather, the moment is immediately aestheticised and brought within Che's world view, fodder for his world-weary poise. The thrill that Che experiences is tied to 
his sense of empty time taking on significance, of "unpredictable consequences": a moment of decision granting temporal shape to the instant, a parodic reprise of the revolutionary time absent from his quotidian post-revolutionary meandering. But it is also a defence mechanism: the capacity to distance himself from loss through the deployment of style.

The scene on Mandela Bridge points to the incommensurable: the contrast between the bridge, with its concrete presence, its plenitude of symbolic meaning, and its surroundings, conspicuously evacuated of any clear historical meaning. Thinks Che, "To my mind, no man should hold the power of life and death over others. But to his mind, there are perhaps compelling reasons to murder strangers in cold blood" (Mohlele 2013, 27). This sardonic moral relativism registers the receding of the overarching allegory of emancipationist redemption and its replacement by an entrepreneurial dog-eat-dog order in which right is purely an expression of force. Che's mugging, on this very icon of aspirational postapartheid meaning, thus crystallises the post-revolutionary loss of political focus. Indeed, Mandela Bridge merely foregrounds the loss of the very emancipatory meta-narrative it was intended to embody. It thus marks the end of a post-apartheid form of social cohesion anchored by the shared horror of the TRC and the emergence of an entropic social order. ${ }^{9}$ But this is not the last we see of Mandela Bridge. With its symbolic baggage of unity and rainbowism, it becomes a leitmotif of the protagonist's wanderings through the city, a place from which his disappointed philosophising finds an anchor. Against the backdrop of Mandela Bridge, Benjaminian empty time slips imperceptibly into Scott's ruined time: a time bearing the imprints of thwarted revolutionary desire. In its juxtaposition with the remnants of futures past, time becomes ruined rather than merely empty:

I continue with my walks to the Nelson Mandela Bridge, for a view of the cityscape, a glance into the faces of passing multitudes for whom freedom is a mockery of all things decent. A disease sweeps across the land. I cannot see an end to everyone wanting to be a Comrade Q. In certain ways, Comrade Q has ceased to be a mere ghost wielding influence, has become a force to be reckoned with. Eighteen years behind bars. For this? But how do I tell the multitudes that Comrade Q is, still, just a ghost, a shadow that lurks in overpriced private bars and exclusive hotels, in sprawling palatial homes and at fashionable funerals, in imported Mercedes Benzes with sonorous engine tones? And so, despairing, I watch from the sidelines while the ghost wrecks our dreams. I call silently on the stars above to shake us from our heedless slumber, in beds soaked with the urine of orphans and the blood of slain men of goodwill. These musings, disturbing and draining, leave a bitter taste in my mouth. (Mohlele 2013, 85)

The world Che paints here is one familiar from the African novel of post-independence disenchantment: lost illusions, an elite class of politically connected kleptocrats (the ubiquitous "Comrade Q") enriching themselves via the extractive economy left by the colonisers. On one level, it is a portrait of the supersession of the inequalities of the apartheid era with the new inequalities of unconstrained capitalism. Let us ignore the moral rectitude of the narrator (whose delusions of a salvific mission might be part of the novel's satire) and focus on his experience of time. What grants the passage its power is the way that, through the catalyst of Mandela Bridge, dream brushes up against reality, the spectral against the actual and forceful. We are positioned here not in the time of interregnum or historical open-endedness, but at its end. There is 
a sense of the congealing of a new order that lacks historical legitimacy (the ghostliness Che perceives).

The narrative tracking of the city thus creates a geographical paradox: the city is in most respects physically unified - Che traverses its most dissonant parts, at one point even illicitly snooping through the Dark Figure's flat, ostensibly in search of a motive behind the attack - yet it is unified by a symbol, Mandela Bridge, that seems increasingly hollow. Che's flânerie thus forecloses those forms of the now that might refashion or overwrite the past, and repeatedly returns to a scene of lost utopian promise. A question arises. Is this compulsive return to Mandela Bridge and the aspirations it represents then a pathological attachment that should be severed? Or is it rather a moral centre, casting into relief the degree to which the present has fallen short of its promises?

\section{Structures of disappointment}

In a well-known essay, Eric Worby and Shireen Ally write that "[i]t is as if to live in South Africa's historical present is necessarily to inhabit what Abbas would call a recurrently 'imploding myth, a structure of disappointment" (2013, 474). Disappointment is a blanket term that covers those multiple forms of post-apartheid affect - melancholia, nostalgia, haunting - in which the past is "enfolded" within the present. ${ }^{10}$ Mandela Bridge, as it is figured in this text, could be considered a concrete, geographically embedded structure of disappointment. In its reverential, melancholic handling of so prominent a piece of urban furniture as Mandela Bridge, Small Things marks its distance from the dominant wave of post-apartheid Johannesburg fiction. It is a text far less invested in imagining forms of the new that might emerge from the debris of the post-apartheid city, less willing to detach itself from the promises of the past. Rather, it is filled with lingering desires and attachments that cannot be severed. This holds, too, at the level of the novel's central romantic plot. Small Things is a story of disappointment both personal and political: the pallid reality of a democratic South Africa is mirrored by the pallid reality of Che's unrequited passion for Desirée, first ignited in his Sophiatown youth, finally consummated two decades later upon Che's release from prison. "Che" and "Desirée": the names are signifiers, respectively, of revolutionary desire and the object of that desire. Like the democratic nation that was yearned for, Che does eventually attain Desirée. But the anticipated bliss of Che's reunion with his object of desire, after 18 years of imprisonment, is marred by the discovery that he is "courting a stone" (Mohlele 2013, 37). Technically consummated but never satisfying, Che's final but hollow possession of Desirée echoes the nominally emancipated South Africa that nonetheless seems bereft of meaningful freedom.

So far this appears a straightforward national allegory. But the web of disappointed desire is tangled: Che is in love with Desirée, who is incapable of fully giving herself to him. Desirée is married to Amazu, a Nigerian mathematician, whom she does not love but who is financially stable. Che embarks on a secondary passionate romance with Mercedes, the daughter of a Cuban exile he meets during his urban peregrinations. Mercedes falls in love with Che, but Che cannot finally wean himself from his longterm attachment to Desirée. Thus, this second chance at love also ends in failure, as Mercedes decides to return to Cuba without him. Another frustrated lover, Benito from New York, enters the scene in the form of a barrage of passionate love letters addressed 
to Mercedes. Undone by his continued passion for her, he barrages her with a slew of love letters, in a coup de grace mailing to her his shaved-off eyebrows.

There is a strong element of farce in this that destabilises our initial allegorical reading: the allegory becomes in effect an allegory of the breakdown of allegory. I want to note the hidden affinity between the amatory and the world historical here. Through these tangled narratives of failed and unrequited love, the novel creates a tragicomic structure of romantic disappointment that stands in for its political disappointments. I am not the first to note that the amatory and the political-historical are inextricably entangled. Freud remarks in "Mourning and Melancholia" (Freud 1989) that political attachments are often stand-ins for failed romantic ones, compensations for lost love. Che's initial passion for political journalism is indeed his way of channelling his frustrations over Desirée. But by the novel's narrative present, it is the other way around: amorous relationships are embarked upon because they seem to offer some tenuous stability in the absence of any sustainable political horizon. Indeed, Desirée is bound up inextricably with Che's memories of Sophiatown, and her loss with its destruction. Desirée thus serves as a stand in and consolation for political loss.

This love plot, then, begins with a singularly focused desire and ends in diffuse entanglements, suggesting at an allegorical level a kind of historical entropy, a loss of focus. This entropy does not stop with Cuba. An entire sediment of the world-historical has filtered into Che's narrative: a global archive of the twentieth century's most convulsive political events, starting, of course, with Che's nickname. His narrative is strewn with the debris of world-historical events: a "Father Goebbels" teaches Che in high school; the abandoned Dachshund Che briefly adopts he names Benito (one presumes after Mussolini); in the background is Truman's bombing of Hiroshima (Mohlele 2013, 7), the Oklahoma bombings and the later World Trade Center bombings (47), Saddam Hussein "fished from a hole in Tikrit" (102). As is the case with Mandela Bridge, world history enters in the mode of bathos and irony. There is no clear pattern to these events. They range from symbols of unmitigated historical catastrophe (Mussolini, Goebbels, 9/11) to those that belong to a more ambivalent political legacy, namely Cuba.

These are signals of History in its grand, world-historical, Hegelian guise. Yet the particular positive or negative, liberatory or oppressive political valences of these events are beside the point. Notably, these political signifiers are severed from their causes. We get no sense of which ideas are being fought for, of what animates these struggles: only discrete names and events, the detritus of history. The great political passions that animated the twentieth century - a tapestry of intertwined catastrophes - are here reduced to a mediated jumble.

As the Latin-American side plot (the Cuban love interest, Che's grandiose nickname, and intertextual debts to Gabriel García Màrquez) signals, part of the fallout of this is a strong yearning to have experienced an alternate history of revolution instead of a transition. The Cuban revolution of course instituted a radically new social order, one that did not lose focus or accommodate itself to an emergent neo-liberal global order. In this sense, it is a kind of "other" of the South African transition. Yet as we come to know more of the story of Mercedes and Gabriel, it becomes clear that this idealised other of the South African transition is an illusion. In her final letter to Che from Cuba, Mercedes presents a dejected figure. Her father Gabriel is dead; Mercedes herself has 
become "a chubby weaver of baskets" (Mohlele 2013, 100) in a morose world of "sugar cane plantations and rum distilleries" (99). ${ }^{11}$ Part of the function of this global web of disappointment - a kind of world-historical blues - is to place the South African experience within a global sphere and remove from it its aura of exceptionality. But it also the product of a melancholic relationship to history. Thus, Che repudiates the world-historic register even as it is incorporated, consigning it to an ironic stratum of his quotidian life: his dog, his high-school teacher, the TV screen. Relegating catastrophic histories to quotidian life allows Che to reconfigure his relationship to the political as one of ironic or sardonic indifference. More, even: endowing the quotidian with world-historical nomenclature is a means of enacting a kind of contemptuous agency over the political: at one point, Che engages in conversations about struggle politics with his dog Benito.

Scott notes that the conventional mode in which anti-colonial struggle is narrated is Romance: the banishment of an oppressive present for a triumphant future in which the sacrifices of struggle will be redeemed. Scott argues for the replacement of this mode by tragedy. Tragedy provides a structure that enframes and ennobles the susceptibility of human achievements to inversion, collapse, contingency - a narrative structure and modal form more capable of encompassing the disenchantments of the post-liberation state (Scott 2014, 180). Scott's argument is particularly powerful because it implies that the post-revolutionary condition not only gives rise to different energies and different temporalities but also requires new genres.

\section{Post-revolutionary allegory/post-apartheid tragicomedy}

Thabo Tsehloane, noting the absence of either "honeymoon literature" or the "literature of disillusionment" in the post-apartheid period, has advanced the compelling thesis that post-apartheid narratives are often characterised by the "ambivalent desire for a utopia that they can neither access nor dismiss" $(2010,81)$. These narratives "attempt to satisfy a yearning for a different society while remaining conscious of this hope as futile." For Tsehloane, this "futile yearning" is managed through the use of either tragic and comic forms (81). How might this thesis help us frame Small Things? Mohlele's writing contains neither the triumphalism of Romance nor the ennoblement of Tragedy. Indeed, Che displays contempt for the latter. "Tragedy," thinks Che after his shooting, "It might as well be comedy" (Mohlele 2013, 32). Yet the novel is clearly no comedy, with its reconciliations. Does it then make sense to think of Mohlele's novel, not as a novel of disillusionment, but rather - bringing both strands of Tsehloane's thesis together - as tragicomedy? Its humour is muted: it might elicit at best the occasional wry smile, rather than the existential laughter of Beckett or Ionescu. But there is some form of wry surrender to entropy that buoys the narrative. This might be the central function of love in the plot. Love is of course a continual disjointing, a confrontation with contingency and otherness (as in Scott's tragic understanding of the political). Yet amatory failure is tragicomic rather than tragic: the catastrophes of love are individual, and love is, to a certain degree, renewable.

Thus, I am tempted to complicate Leon de Kock's claim that post-apartheid literary production is characterised by "a widely perceived sickness in the body politic, where the plot, metaphorically speaking, is thought to have been lost" $(2017,9)$. Yes, the creeping 
entropy of both romantic and political desire, as opposed to their single-minded clarity in Che's memories, allegorise a plot loss. However, and crucially, despite the diffuseness of its plot and the complex entanglements of its characters, Mohlele's yoking of the amatory to the political functions to create a form of post-revolutionary allegory in which the memory of an anticipated future is continually brought back to the fore rather than allowed to slip away in favour of new desires.

Age is an important factor in Mohlele's aesthetics. Although Mohlele himself is a young writer, his protagonists are physically infirm, looking back upon their lives, their habits too deeply ingrained to start afresh. It is noteworthy that Che has the option to leave his vagabondage: to jump on the gravy train through his struggle connections or to abandon his hopeless love of Desirée in favour of the far more pliant Mercedes. Yet he does not. This commitment to Desirée lies ambivalently on the boundary between utopian hope and pathological attachment.

This is clearest in the absence of a clean romantic denouement. Although Che never completely "possesses" Desirée, Desirée also never completely rejects Che. At one point, Che, Amazu, and Desirée live in a mutually consensual menage à trois. But at the end of Che's narrative, Desirée has suffered a debilitating stroke. Che and Amazu are initially told she is dead; this turns out to be a false alarm: she is in fact comatose. By the end of the novel, she is alive but in a vegetative state. Thus, Che's desire for her also rests in limbo: even as he leaves the city to die alone and unsung, he "still think[s] Desirée is the only soul for whom my heart throbbed" (Mohlele 2013, 107).

This love story, like the story of the South African transition itself, comprises a series of tumultuous hopes, compromises, and disappointments that lack a definitive ending in either comedy (he gets the girl) or tragedy (she dies). The kinds of obsessive passions it signals are similar to those at play in Che's decision not to follow Mercedes back to Cuba and instead to remain in "an Africa that is a moth refusing to burn" (Mohlele 2013, 62). The moth refusing to burn: the persistence of a potentially self-destructive desire for an impossible object. Che is thus still psychologically wedded to the structure of revolutionary time, even as he acknowledges its disintegration. Both of these are images of a desire that remains in limbo, that cannot be relinquished but cannot be satisfied.

The production of a form of desire whose object is always just out of reach seems essential to Mohlele's poetics. In the context of the reification of national history, Che's pathological obsession with Desirée becomes a mode, if not of keeping alive the promises of the past, at least of resisting accommodation with the present. It is useful to remember that disappointment, in Worby and Ally's reading, has a dual valence. Disappointment is not only "about the dashing of expectations," it is also "an awareness that things are not in their appointed places" $(2013,474)$. That is, dis-appointment, in its hyphenated form given it by Worby and Ally, yokes the fallen actuality of the present together with the original promise that it failed to meet. Unlike disillusionment or disenchantment - two other phrases commonly deployed - disappointment holds on to the possibility that things may yet get better.

We enter here a world of what Wenzel memorably calls "unfailure," a concept I borrowed at the start of this paper to describe the status of revolutionary desire post-1994. Wenzel writes that unfailure, by "holding a sense of inevitability in abeyance - either inevitable devastation or inevitable liberation - might recover modes of dreaming difference" $(2009,28)$. One might 
also turn to Benjamin, upon whose foundation Scott of course builds his theorisation of ruined time. In his late writings, as the course of European modernity increasingly revealed itself to be calamitous, Benjamin famously turns away from the Marxist admonition to imagine revolutionary futures. Instead, in his "Theses on the Philosophy of History" as well as in his Arcades Project (Benjamin [1958] 1968, [1982] 2002), Benjamin finds utopian possibility not in the future but in the past: in particular, in images of futures that did not come to pass. These images are not necessarily revolutionary in themselves. Rather, as Benjamin makes clear in the Arcades Project, they are often images of stillness, images of possibility that inhere in objects and images before they have slipped into the long historical continuum by whose workings they are inevitably debased and corroded. In the act of perceptually grasping these images of stillness, the past could be, to use Benjamin's favoured term, "blasted" out of the historical continuum (Benjamin [1958] 1968, 263), and all assumptions of the necessary teleology of history suspended. ${ }^{12}$ In considering how the reader might come away from Mohlele's tale of disappointed hopes, it is striking that, more than anything else, one is left with a historical image: not a scene of revolution or of movement, but a still shot of the empty, featureless city juxtaposed against the drama of Mandela Bridge. It is hard not to read this as a Benjaminian dialectical image, one that binds the fallen after-history of an idea with its utopian beginnings.

If we take a step back from Mohlele's novel to survey the social landscape of South Africa post 2012, we see waves of nationwide protests that went under the broad banner of Fallism: \#RhodesMustFall, \#FeesMustFall, \#ZumaMustFall. These were movements of great theatricality which swept aside the iconography of a revolution completed (the elderly Mandela) and claimed lineage within a longer line of uncompromising struggle figures who had receded from view under the new liberal dispensation (Steve Biko, Robert Sobukwe). The refined melancholy of Small Things seems deeply anachronistic in the post-2012 affective field, which is overwhelmingly characterised by rage rather than loss, by the passions of youth rather that the regrets of age. Indeed, amid the stridency of fallist politics, Mohlele's fastidious revulsion towards the political realm seems an irrelevant whisper. Yet, while the openly revolutionary energies of the fallist movement seem a world apart from the resigned satire of Mohlele's novel, both are underpinned by the desire to seize from the post a seemingly moribund temporality of emancipation and re-insert it - in of course very different ways - into the increasingly plotless post-apartheid present.

\section{Notes}

1. Scott relies on a historical-theoretical framework that has broad overlaps with that of global revolutionary movements throughout the twentieth century. If South Africa did not experience a failed revolution - indeed, did not experience a revolution proper at all - it nonetheless underwent a drastic shift in temporal expectations. A temporality in which an oppressive past would be succeeded by an emancipated future gave way to another far more entangled sense of time's meaning. Despite important differences - which I discuss in the conclusion - Scott's insights can thus give us some purchase on South Africa after the end, not only of official apartheid, but of certain imagined futures of what South Africa would be after apartheid.

2. This uncertainty around the status of emancipation is visible in the increasingly complex ways in which the nation has begun to stage its relationship to its past. In the academy, 
there is talk of the transitional and the post-transitional, of post-post-apartheid and postanti-apartheid; in politics, of a "suspended" revolution and a revolution deferred. Recent waves of political protest have self-consciously placed themselves in the lineage of antiapartheid struggle - all evidencing a profound desire to cathect the slippery present onto a meaningful historical meta-narrative. On these periodisations, see Samuelson (2010), Frenkel and MacKenzie (2010), Akpome (2016); on revolution, see Habib (2013), and Murray (1994).

3. For studies of this apartheid haunting under the guise of melancholia and/or nostalgia, see Truscott (2011), Hanson (2012), and Dlamini (2010, 2014).

4. I am not suggesting that the allegory of emancipatory redemption embodied by "1994" no longer plays a role in the public sphere. To the contrary, there is a widespread remobilisation of emancipatory narratives nationwide, particularly among youth. Rather, my argument is that it has crept back into national consciousness as an object of scrutiny rather than as a fait accompli. My interest here is in not in the recent and spectacular remobilisations of this narrative, but rather in the widespread experience of its renewed centrality. While for many South Africans, it is once more a source of utopian investment and political action (see Frenkel and Gupta 2019 in the introduction to this special issue), for many others, it is associated with a painful betrayal.

5. Andrea Spain makes a similar observation about the use of the passive voice in Nadine Gordimer's The Pickup (2002). Gordimer's style, argues Spain, “emphasizes the past's force divorced from individual actors" (2012, 759). Spain's larger argument regarding Gordimer's fiction - that it renders the way in which the forces of post-colonialism deeply and imperceptibly inform "individual and collective action" in the present (749) - is also applicable to Mohlele's writing. Mohlele's narrators always seem to be stylistically negotiating a relationship with overweening historical forces.

6. Scholars have developed Nuttall's premise in a number of directions. Spain contends, in her reading of the work of K. Sello Duiker, that there is a privileging of "a temporality of encounter or becoming over that of promise" $(2016,417)$. In my own writing, I have argued that post-apartheid Johannesburg literature sees a breakdown of national allegory and its replacement with the imagining of micro-futures (see Wright 2018).

7. There is a class of Johannesburg structures - the Constitutional Court, the Apartheid Museum, Mandela Bridge - that carry on their shoulders the ambitions of post-apartheid nation-building. These structures do not quite belong to the world of remaking and becoming I describe elsewhere (see Wright 2018). Mandela Bridge is a symbol of a very specific "future past": the overcoming of the disunity of the apartheid city.

8. See the immense variety of municipal and "city-branding" websites featuring the bridge.

9. Lindsey Bremner, writing of an earlier post-apartheid period: "What anchors social cohesion is no longer the traumatic-mythic, but the traumatic sublime ... no longer human tragedies but a horror so deep it cannot be sublimated into tragic dignity" (2010, 238-239).

10. For a recent study of South African literature as a literature of disappointment, see Van der Vlies (2017).

11. Danyela Demir has alerted me to the intertextual reference to Gabriel García Màrquez's A Hundred Years of Solitude, who similarly creates a world in which a succession of political hopes and disappointments is matched only by romantic ones. Mohlele signals this intertextual debt in the Cuban story, where, like the patriarch of the Buendía clan in Solitude, the character Gabriel spends his final days listening to a transistor radio under a mulberry tree. Mohlele's vision is less exuberant but also less apocalyptic than García Màrquez's, more fraught with the ambivalences of post-apartheid, with its partial successes, partial failures, its unpredictability. In the gigantic political allegory of One Hundred Years of Solitude, the saga of a single family dynasty in a remote town takes on a quasi-mythical scale, becoming a microcosm of an entire history of modernity. Mohlele is far more modest, tending not to the epic or tragic but to the tragicomic and bathetic: the amorous relationships are tentative and result in no progeny. The sense is not of every 
page being "rammed full of life beyond the capacity of any single reader to absorb" (Bloom 2009) but of a vast shadow world of stories not fully told, of neglected lives. This is not the only parallel with García Màrquez's world. The romantic plot of Small Things, with its endlessly deferred love between Che and Desirée, bears strong resemblance to Love in the Time of Cholera (although the latter ends "happily").

12. For this argument, I am indebted to the anonymous review of this article and to Susan Buck-Morss's excellent discussion of Benjamin's understanding of the historical image. See Buck-Morss (1989, 218-219).

\section{Disclosure statement}

No potential conflict of interest was reported by the author.

\section{Notes on contributor}

Timothy Wright is an Assistant Professor of English Literature at Bilkent University. The accompanying article was written on a post-doctoral research fellowship at the University of Johannesburg. Wright's current research examines cultural production in post-apartheid Johannesburg. He is also working on a book manuscript on disconsolation in the global novel.

\section{References}

\section{Literature}

Akpome, A. 2016. "Towards a Reconceptualisation of '(Post)Transitional' South African Cultural Expression." English in Africa 43 (2): 39-62. doi:10.4314/eia.v43i2.2.

Benjamin, W. [1958] 1968. "Theses on the Philosophy of History." In Illuminations: Essays and Reflections. Translated by H. Zohn, 253-264. New York: Schocken.

Benjamin, W. [1982] 2002. Arcades Project. Translated by H. Eiland and K. McLaughlin. Cambridge, MA: Harvard University Press.

Bloom, H., ed. 2009. One Hundred Years of Solitude (Bloom's Modern Critical Interpretations). New York, NY: Infobase Publishing.

Bremner, L. 2010. Writing the City into Being: Essays on Johannesburg, 1998-2008. Johannesburg: Fourthwall Books.

Buck-Morss, S. 1989. The Dialectics of Seeing. Cambridge, MA, and London: MIT Press.

De Kock, L. 2017. Losing the Plot: Crime, Reality, and Fiction in Postapartheid Writing. Johannesburg: Wits University Press.

Dlamini, J. 2010. Native Nostalgia. Johannesburg: Jacana.

Dlamini, J. 2014. Askari: A Story of Collaboration and Betrayal in the Anti-Apartheid Era. Johannesburg: Jacana.

Frenkel, R., and C. MacKenzie. 2010. "Conceptualising 'Post-Transitional' South African Literature in English.” English Studies in Africa 53 (1): 1-10. doi:10.1080/ 00138398.2010 .488331$.

Frenkel, R., and P. Gupta. 2019. "Yo-Yo Culture: Thinking South Africa after Marikana." Social Dynamics 45 (2): 1.

Freud, S. 1989. "Mourning and Melancholia." In The Freud Reader, edited by P. Gay, 584-588. New York/London: W.W. Norton and Company.

Habib, A. 2013. South Africa's Suspended Revolution: Hopes and Prospects. Johannesburg: Wits University Press.

Hanson, T. B. 2012. Melancholia of Freedom: Social Life in an Indian Township in South Africa. New Jersey: Princeton University Press. 
Kruger, L. 2013. Imagining the Edgy City: Writing, Performing, and Building Johannesburg. Oxford: Oxford University Press.

Malec, J. 2015. “Writers Can't Control Everything Related to Their Work': Interview with Masande Ntshanga, Author of the Reactive." Accessed 30 November 2017. http://bookslive. co.za/blog/2015/02/03/writers-cant-control-everything-related-to-their-work-interview-withmasande-ntshanga-author-of-the-reactive/

Maserow, J. N. D. 2014. The Shadow of History. Accessed 24 July 2017. http://aerodrome.co.za/ahistory-of-shadows/

Mohlele, N. 2008. The Scent of Bliss. Cape Town: Kwela Books.

Mohlele, N. 2013. Small Things. Pietermaritzburg: University of KwaZulu-Natal Press.

Mokoena, H. "The Black Interpreters and the Arch of History." In The Colour of Our Future, edited by H. Mangcu, 169-183. Johannesburg: Wits University Press.

Mpe, P. 2001. Welcome to Our Hillbrow. Pietermaritzburg: University of Natal Press.

Murray, M. J. 1994. Revolution Deferred: The Painful Birth of Post-Apartheid South Africa. London: Verso.

Ntshanga, M. 2014. The Reactive. Cape Town: Umuzi.

Nuttall, S. 2004. "City Forms and Writing the 'Now' in South Africa." Journal of South African Studies 30 (4): 731-748. doi:10.1080/0305707042000313988.

Samuelson, M. 2010. "Scripting Connections: Reflections on the Post-Transitional." English Studies in Africa 53 (1): 113-117. doi:10.1080/00138398.2010.488348.

Scott, D. 2004. Conscripts of Modernity: The Tragedy of Colonial Enlightenment. Durham, N.C.: Duke University Press.

Scott, D. 2014. Omens of Adversity: Tragedy, Time, Memory, Justice. Durham, N.C.: Duke University Press.

Spain, A. 2012. "Event, Exceptionalism, and the Imperceptible: The Politics of Nadine Gordimer's the Pickup.” Modern Fiction Studies 58 (4): 747-772. doi:10.1353/mfs.2012.0060.

Spain, A. 2016. "Transitional Encounters: Practices of Queer Futurity in K. Sello Duiker's Thirteen Cents." Safundi 17 (4): 416-433. doi:10.1080/17533171.2016.1233622.

Truscott, R. 2011. "National Melancholia and Afrikaner Self-Parody in Post-Apartheid South Africa." Psychoanalysis, Culture, and Society 16 (1): 90-106. doi:10.1057/pcs.2010.42.

Tsehloane, T. 2010. "The Tragic and the Comic: Sello Duiker's and Niq Mhlong"s Contrasting Views of Post-Apartheid Society." English Studies in Africa 53 (1): 79-90. doi:10.1080/ 00138398.2010.488342.

Van der Vlies, A. 2017. Present Imperfect. Oxford: Oxford University Press.

Wenzel, J. 2009. Bulletproof: Afterlives of Anti-Colonial Prophecy in South Africa and Beyond. Chicago: University of Chicago Press.

Worby, E., and S. Ally. 2013. "The Disappointment of Nostalgia: Conceptualising Cultures of Memory in Contemporary South Africa." Social Dynamics 39 (3): 457-480. doi:10.1080/ 02533952.2013.852371.

Wright, T. 2018. "Mutant City: On Partial Transformation in Three Johannesburg Narratives." NOVEL: A Forum on Fiction 51 (3): 417-437.

\section{Filmography}

Necktie Youth. 2015. Directed by Sibs Shongwe-La Mer. 93 minutes. Urucu Media, Whitman Independent, 100\% Halal. 